\title{
Mangelfull hørselsrehabilitering i Norge
}

\author{
Hørselsrehabiliteringen i Norge har et ensidig fokus på høreteknisk tilpasning. Hørselshemmede har \\ en betydelig overbelastning av muskel- og skjelettsystemet som en konsekvens av hørselstapet. Brukerne \\ bør få mer kunnskap om og erfaring med hvordan god kroppsbevissthet og opptrening av balanseevnen kan \\ frigjøre oppmerksomhet og energi, slik at unødvendige sykmeldinger og uføretrygd unngås.
}

Hørselsnedsettelse hos barn og voksne er et økende problem, og det er anslått at $25 \%$, det vil si over en million nordmenn, vil være hørselshemmet i 2020 (1).

Dårlig hørsel krever full oppmerksomhet rettet mot den som snakker, inkludert øyekontakt og munnavlesning. Når høretekniske hjelpemidler ikke gir tilstrekkelig taleforståelse, kombineres munnavlesning med lydrytme og gjetting. Dette er uhyre komplisert og krever intens konsentrasjon. God tilrettelegging med høretekniske hjelpemidler, gode lytteforhold og samtalepartnere med tydelig uttale og kroppsspråk er viktige forutsetninger for at kommunikasjonen skal lykkes. Men mange hørselshemmede opplever liten forståelse fra omgivelsene.

Det er mer enn det objektive hørselstapet som avgjør hvordan hørselshemmede greier seg i storsamfunnet. I all samhandling mellom mennesker skjer en helhetlig fortolkningsprosess, og for hørselshemmede er denne fortolkningsprosessen spesielt krevende fordi de ikke hører alt som sies. Når man stadig opplever å misforstå og ikke henger med i samtalen, daler selvtilliten og det blir vanskelig å oppleve seg som likeverdig samtalepartner. Det påvirker i neste omgang forventningene man har til seg selv og hvilke muligheter man har til å nå sine mål som likeverdig deltaker i storsamfunnet.

\section{Hørsel, syn og muskel- og skjelettsystemet}

Når hørselshemmede ikke mottar tilstrekkelig informasjon fra hørselssenteret til å oppfatte lydinntrykkene omkring seg korrekt, vil de kompensere med andre sanser. Synet brukes til munnavlesning og til å orientere seg om lydkilden og lydretningen, men fungerer dårlig som kompensasjon for hørselen. Muskel- skjelettsystemet mobiliseres i stor grad når personen anstrenger seg for å oppfatte hva som sies. Over tid fører uttalte muskelspenninger ofte til uhensiktmessige bevegelser og dårlig balanse, noe som i sin tur bidrar til at synet og nakken overbelastes for å opprettholde postural kontroll.

Progredierende hørselstap krever stadig omstilling av hørselen. Usikkerhet som følger med det aldri å være helt sikker på hva som sies, gjør at man lett spenner seg, puster overflatisk og generelt er i en beredskapsposisjon (2). Vi har selv arbeidet med bevegelsesgrupper for hørselshemmede, og vår erfaring er at mange har dårlig balanse og kroppsbevissthet. Dårlig balanse fører til utstrakt bruk av synet ved at man fikserer blikket på bestemte punkter, nært eller fjernt $(3,4)$. Det vanskeliggjør kartlegging av og oppdatering om hva som foregår i omgivelsene. For hørselshemmede har dette omfattende konsekvenser. Lyd og taleoppfattelse foregår i syntese mellom syn og hørsel, og det er avgjørende at synet fristilles til munn- og kroppsavlesning og orientering om lyden i rommet. God bevegelig balanse - det vil si stabilitet kombinert med fleksibilitet og evne til nyansert tilpasning - krever tydelig opplevelse av kroppslig forankring der personen stoler på sine proprioseptive sanser (5). All sansing er avhengig av sentralnervesystemets bearbeiding for å kunne følges opp med adekvat reaksjon. Jo mer hensiktmessig de automatiske reaksjonene er, desto mindre energi går med til uheldige kompenseringer.

En av forfatterne av dette innlegget er selv døv, dobbeltsidig cochleaimplantert og psykomotorisk fysioterapeut, og har flere års erfaring med rehabilitering av voksne hørselshemmede ved Briskeby skole og kompetansesenter. Brukerne rapporterer om plager med tretthet og smerter i muskelog skjelettsystemet, og mange strever med å fungere $\mathrm{i}$ arbeid og sosiale sammenhenger. Vår erfaring er at når de får kunnskap om konsekvenser av hørselstap og praktisk hjelp til å håndtere ulike lyttesituasjoner, blir de mindre slitne, får mindre smerter og blir tryggere i kommunikasjon med andre.

\section{Større sammenhenger}

I dag finnes det ikke god statistikk over hvor mange som faller ut av arbeidslivet eller blir uføretrygdet på grunn av hørselshemning. Det har blant annet sammenheng med at sekundære plager til hørselshemningen ofte blir oppgitt som medisinsk årsak til arbeidsuførhet. Kursdeltakerne ved Briskeby skole og kompetansesenter rapporterer at de ofte blir sykmeldt og uføretrygdet uten at de har fått hjelp til å takle sin hørselshemning. Ifølge dem er det sjelden primærleger og spesialister henviser hørselshemmede til fysioterapeut. De forteller om hjelpeløshet fra både NAV og leger når det gjelder hva som kan gjøres for å mestre livet sosialt og $\mathrm{i}$ arbeid.

I dag har vi mye kunnskap om sammenhenger mellom stress, kroppslig fungering og mental tilstedeværelse $(3,6)$. Basert på slik kunnskap og kliniske erfaringer vil en tilnærming med vekt på å utvikle brukernes kroppslige trygghet og forankring kunne frigjøre deres oppmerksomhet og energi, og dermed øke mulighetene for at flere kunne delta aktivt og på like fot med andre i samfunns- og arbeidsliv.

Det trengs også bedre samhandling mellom leger og fysioterapeuter for å hjelpe hørselshemmede, og dessuten studier og statistikker over hørselshemmedes fungering og arbeidsuførhet. Medfører prognosen om at omtrent en million nordmenn vil være hørselshemmet i 2020 riktighet, er dette et viktig problemområde også i dagens debatt om sykefravær.

\section{Eline Thornquist}

eth@hib.no

Høgskolen i Bergen

Postboks 7030

5020 Bergen

\section{Inger Anita Herheim}

Voss fysioterapi

Voss

Oppgitte interessekonflikter: Ingen

Litteratur

1. Hearing impairment among adults (HIA). Oslo: Senter for medisinsk metodevurdering, Sintef, 2001.

2. Fjose IA. Et hørende liv med cochleaimplantat. Tidsskr Nor Lægeforen 2005; 125: 3303.

3. Brodal P. Sentralnervesystemet. Oslo: Universitetsforlaget, 2007

4. Brodal P. Det nevrologiske grunnlaget for balanse. Fysioterapeuten 2004; 71, nr. 8; 25-30.

5. Thornquist $\mathrm{E}$, Bunkan HB. Hva er psykomotorisk behandling. Oslo: Gyldendal, 1986.

6. McEwen BS, Wingfield JC. The concept of allostasis in biology and biomedicine. Horm Behav 2003; 43: $2-15$

Manuskriptet ble mottatt 4.5. 2010 og godkjent 2.9. 2010. Medisinsk redaktør Anne Kveim Lie. 